\title{
SERUM LIPOIDS AND PROTEINS IN HYPERTHYROIDISM ${ }^{1}$
}

\author{
By E. B. MAN, E. F. GILDEA, AND J. P. PETERS \\ (From the Departments of Psychiatry and of Internal Medicine, Yale University, School of \\ Medicine, New Haven, and the Medical Service of the New Haven Hospital, New Haven)
}

(Received for publication August 2, 1939)

It has been stated frequently that the level of serum cholesterol is as valuable an index of hyperthyroid activity as the basal metabolic rate. An examination of the literature, however, reveals controversial material to support this dictum. The present study was undertaken to determine how closely the level of serum cholesterol is related to the degree of thyroid activity and whether it is a useful criterion in the diagnosis of hyperthyroidism. It was thought of importance also to know if changes in the level of serum cholesterol after the administration of iodine might help in diagnosis in those questionable hyperthyroid patients whose basal metabolic rates do not respond to the ingestion of Lugol's solution. In addition to the cholesterol, basal metabolic rates, serum fatty acids, phosphatides and proteins of 65 patients with symptoms of hyperthyroidism have been determined at frequent intervals to learn: (1) whether there is an inverse relationship between basal metabolic rate and serum cholesterol, lipoid phosphorus, fatty acids and proteins; (2) if these serum constituents increase when the basal metabolic rate falls after the administration of iodine; and (3) if thyroidectomy always increases these components. The data on only 43 patients are presented in the tables because the other 22 patients were not completely studied. There were about 430 samples of blood sera in which the three lipoid fractions and proteins were determined during the 3 or more years that many of the patients have been followed.

Hurxthal, Hunt and co-workers have studied the largest group of patienţs $(23,24,25,26,38)$. Although they have employed a cholesterol colorimetric method described by Bloor in 1922, their results are reliable because they have devoted considerable attention to normal values. They have placed the low limit of normal for their method at $120 \mathrm{mgm}$. per cent, and the high limit at 300

1 This work was aided in part by a grant from the Knight Fund, Yale University School of Medicine. mgm. per cent (26). In the study of patients with hyperthyroid disease these authors have found cholesterol values in a large majority of patients which were close to their low limit of normal. The rest of the values were distributed about equally on both sides of this figure (23). These authors have considered the possible effect of malnutrition on the serum cholesterol and have decided that it is of minor importance (23). They conclude that serum cholesterol is low in hyperthyroidism and that there is a relation between the severity of the disease and the level of cholesterol (23). Recent studies by Boyd indicate that total lipoids and phospholipids, as well as cholesterol, tend to be low in hyperthyroidism (7, $8,9,10,11)$. Thus these recent studies on a large number of patients support the view that severe degrees of hyperthyroidism are usually associated with low levels of serum cholesterol (4, $16,41,45,47)$.

It is, however, probable that there are a considerable number of patients with severe hyperthyroidism who do not have low serum cholesterol or other fractions of the lipoids. A number of workers have reported that in patients with hyperthyroidism the blood or serum cholesterol may be within normal limits $(1,3,15,28,30,44,52)$, or sometimes high $(17,22,29,39,40,51)$. That there is no clear-cut relation between basal metabolic rate and cholesterol is probably due to many factors. Inaccuracies and differences in methods, failure to choose relatively clear-cut examples of hyperthyroidism or to study enough patients, account for some discordant results. Furthermore, in evaluating data, such factors as state of nutrition and hemoconcentration and the condition of the nervous system of the patients have been neglected.

Most of the previous workers have measured only one form of blood lipoid, usually total cholesterol. The problem of cholesterol methods is an old and controversial topic. This matter has been 
discussed by the authors (36) in a paper on the measurement of cholesterol in which it was pointed out that the colorimetric methods were unreliable and subject to errors varying from minus 18 to plus 76 per cent. Schoenheimer (48), and also Kirk, Page, Van Slyke and coworkers $(27,43)$ have recently reinvestigated cholesterol methods and have adopted a method dependent on digitonin precipitation. Even in Bloor's laboratory where the colorimetric and nephelometric methods were revised again and again, a digitonin precipitation method has been developed $(42,53)$. In justice to some colorimetric data it should be recognized that certain workers with a flair for colorimetry, who have carefully devised and checked their own standards and ruled out complicating precipitates and colors, have probably achieved approximately accurate results. In many of the papers on hyperthyroidism not enough details as to technique and range of normal values for the method have been presented to permit evaluation of the results.

\section{MATERIAL AND METHODS}

The 43 patients included in this study, except as otherwise indicated, exhibited most of the symptoms of hyperthyroidism and had basal metabolic rates of more than plus 30 per cent, as estimated from the lowest value obtained from repeated tests. As will be described in detail under DATA, the clinical features of exophthalmos, malnutrition, tremor, restlessness, degree of cardiac enlargement and vasomotor phenomena including sweating, flushing, pulse irregularities and rate, have been carefully evaluated. Evidences of disorders of the endocrine glands other than the thyroid were sought.

The mental and emotional status, degree of vasomotor instability, and neurological status of each patient were studied in the search for underlying nervous system disorders that could not readily be considered as secondary to overactivity of the thyroid (13). Previous investigators have pointed out that the nervous and mental symptoms produced by excessive amounts of thyroid secretion consist of a fine muscular tremor, awareness of rapid heart beat, perspiration, restlessness, irritability, and a feeling of fatigue. In the present study the above symptoms and a moderate degree of anxiety and fear of the illness have been considered as being due to hyperactivity of the thyroid. Other mental symptoms such as marked depression in mood, states of agitation often over trivial or imaginary troubles, severe anxiety and delusions of persecution have been considered as evidence of an underlying nervous system disorder not secondary to overactivity of the thyroid.

Additional evidence in favor of or against the extra thyroid origin of the nervous system disorders was sought in the past history and in the course of the symptoms after thyroidectomy. The story of mental disorders, such as encephalitis and manic depressive psychosis, long before the onset of the characteristic symptoms of hyperthyroidism, and the persistence of these symptoms long after the basal metabolic rate had fallen to zero or below, were considered as supporting the extra thyroid origin of such symptoms. Stress has been laid on these vegetative and central nervous system disorders because recent studies of the authors indicate that elevated serum lipoids are frequently found in patients with these conditions (20).

All of the metabolic studies were made in the morning when the patients were in the post-absorptive state. The basal metabolic rates were measured with the BenedictRoth apparatus under the standard conditions which have been described by Benedict, Dubois and others. The venous blood samples were usually taken after this test or on the following day. They were collected under oil, centrifuged with anaerobic precautions, and the serum analyzed according to methods previously described for cholesterol $(5,36)$, fatty acids $(32,34)$, lipoid phosphorus $(31,36)$, proteins, albumin and globulin (14).

Histopathological studies of the glands were made independently in the Department of Pathology of the Yale University School of Medicine.2

\section{DATA}

In Tables I, II, and III are charted the symptoms of 43 patients as well as the basal metabolic rate and serum cholesterol determined in most instances: before administration of Lugol's; after Lugol's but just before thyroidectomy; 1 to 8 weeks after thyroidectomy; and 4 to 40 months after thyroidectomy. Table I includes 13 uncomplicated hyperthyroid patients; Table II, 9 patients who had a good recovery; and Table III, 21 patients who only had a partial recovery after thyroidectomy. In Tables II and III, the open circles (O) mark the 21 patients with marked disorders of the vegetative and central nervous system, including patients with diabetes and marked vasomotor disturbances resembling those described in a previous paper (37). The remaining $9 \mathrm{pa}$ tients denoted by crosses $(X)$ suffered from a variety of disorders in addition to thyroid disease. Three (A55758, 27339, A57648) had peculiarities of physical makeup suggestive of complex glandular disorders. Five $(96354,625, \mathrm{~A} 43137,70165,84321)$ had long histories of repeated recurrence and removal of thyroid tissue. One (A39091) had cardiac decompensation, hypertension and minimal symptoms of hyperthyroidism.

Enlargement of the thyroid has been graded as + when the gland was slightly palpable, ++ when large, +++ large with bruit, and ++++ when the enlargement was extreme. Cardiac enlargement has been

2 We are indebted to Dr. Harry M. Zimmerman of the Department of Pathology for re-evaluation of this material in connection with the present paper. 
TABLE I

Uncomplicated hyperthyroid patients

\begin{tabular}{|c|c|c|c|c|c|c|c|c|c|c|c|c|c|c|c|c|c|c|c|c|c|c|}
\hline \multirow[b]{3}{*}{$\begin{array}{l}\text { Case number, } \\
\text { age, and sex }\end{array}$} & \multicolumn{7}{|c|}{ Symptoms of hyperthyroidism } & \multicolumn{7}{|c|}{ Complications } & \multirow{2}{*}{\multicolumn{2}{|c|}{$\begin{array}{l}\text { Before } \\
\text { Lugol's }\end{array}$}} & \multirow{2}{*}{\multicolumn{2}{|c|}{$\begin{array}{c}\text { After } \\
\text { Lugol's } \\
\text { before } \\
\text { operation }\end{array}$}} & \multirow{2}{*}{\multicolumn{2}{|c|}{$\begin{array}{c}\text { 1-8 weeks } \\
\text { post } \\
\text { operation }\end{array}$}} & \multirow{2}{*}{\multicolumn{2}{|c|}{$\begin{array}{c}4 \text { or more } \\
\text { months } \\
\text { post } \\
\text { operation }\end{array}$}} \\
\hline & \multicolumn{3}{|c|}{ Cardiac } & \multirow{2}{*}{\multicolumn{2}{|c|}{ 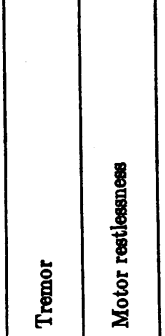 }} & \multirow[b]{2}{*}{ 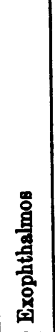 } & \multirow[b]{2}{*}{ 鬲 } & \multicolumn{4}{|c|}{ Brain stem disorders } & \multirow[b]{2}{*}{ 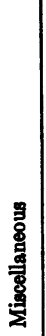 } & \multirow[b]{2}{*}{ 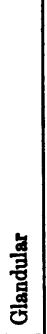 } & \multirow[b]{2}{*}{ 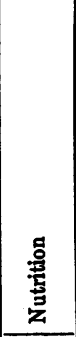 } & & & & & & & & \\
\hline & 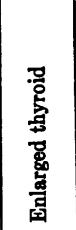 & 䓌 & 褐 & & & & & 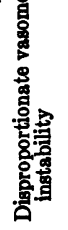 & 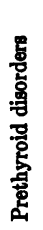 & 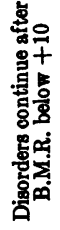 & 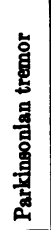 & & & & 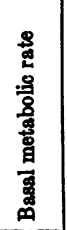 & 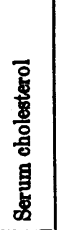 & 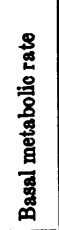 & 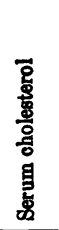 & 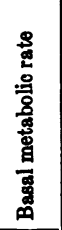 & 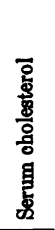 & 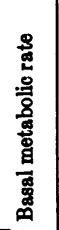 & 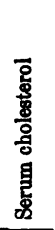 \\
\hline $\mathrm{F} \quad 18$ & ++ & 0 & 150 & $+t$ & ++ & + & ++ & 0 & $\mathbf{0}$ & $\mathbf{0}$ & $\mathbf{0}$ & 0 & $\mathbf{0}$ & - & $\begin{array}{l}\text { per } \\
\text { cent } \\
+51\end{array}$ & $\begin{array}{c}\text { mom. } \\
\text { per } \\
100 \\
c c . \\
75\end{array}$ & $\begin{array}{l}\text { per } \\
\text { cent } \\
+7\end{array}$ & $\begin{array}{c}\text { mom. } \\
\text { per } \\
100 \\
c c . \\
145\end{array}$ & $\begin{array}{l}\text { per } \\
\text { cent } \\
+9\end{array}$ & $\begin{array}{c}\text { mom. } \\
\text { per } \\
100 \\
c c . \\
200\end{array}$ & $\begin{array}{l}\text { per } \\
\text { cent } \\
-8\end{array}$ & $\begin{array}{c}\text { mom. } \\
\text { per } \\
100 \\
c c . \\
181\end{array}$ \\
\hline $\begin{array}{l}\text { A56897 } \\
M \quad 23\end{array}$ & ++ & 0 & 120 & $+t$ & + & + & + & $\mathbf{0}$ & 0 & 0 & 0 & 0 & $\mathbf{0}$ & - & +55 & 125 & & & +2 & 206 & -12 & 175 \\
\hline $\begin{array}{l}\mathrm{A} 44838 \\
\mathrm{~F}\end{array}$ & + & + & 110 & ++ & +++ & $\mathbf{0}$ & ++ & $\mathbf{0}$ & 0 & $\mathbf{0}$ & $\mathbf{0}$ & $\mathbf{0}$ & 0 & -- & +72 & 113 & +7 & 164 & -4 & 240 & & \\
\hline $\begin{array}{l}\mathrm{A} 65412 \\
\mathrm{~F} \quad 19\end{array}$ & ++ & + & 130 & $+t$ & ++ & ++ & ++ & 0 & 0 & 0 & 0 & 0 & 0 & $\mathbf{N}$ & +105 & 114 & +49 & 141 & +9 & 196 & & \\
\hline$\stackrel{\mathrm{A} 82427}{\mathrm{M}} \quad 32$ & ++ & 0 & 125 & ++ & + & + & + & 0 & 0 & 0 & 0 & 0 & 0 & -- & +34 & 120 & +11 & 220 & +5 & 289 & -7 & 290 \\
\hline $\begin{array}{l}\mathrm{A} 65387 \\
\mathrm{~F} \quad 19\end{array}$ & ++ & 0 & 130 & $+t$ & ++ & 0 & ++ & 0 & 0 & 0 & 0 & 0 & 0 & + & +35 & 117 & +13 & 164 & -8 & 202 & -28 & 176 \\
\hline $\begin{array}{l}\mathrm{A} 589330 \\
\mathrm{M} \quad 35\end{array}$ & +++ & 0 & 120 & ++ & + & ++ & ++ & 0 & 0 & 0 & 0 & 0 & 0 & -- & +69 & 116 & +35 & 126 & +2 & 226 & & \\
\hline$F^{8850} 21$ & ++ & 0 & 128 & ++ & ++ & + & ++ & 0 & 0 & 0 & 0 & 0 & 0 & - & +59 & 115 & +15 & 142 & +2 & 175 & & \\
\hline $\begin{array}{l}\mathrm{A} 591400 \\
\mathrm{~F}\end{array}$ & + & + & 125 & $+t$ & + & 0 & ++ & $\begin{array}{l}\text { Exo } \\
0\end{array}$ & $\begin{array}{c}\text { hth: } \\
0\end{array}$ & $\begin{array}{c}\operatorname{mos} d e \\
\text { op }\end{array}$ & $\begin{array}{c}\text { elopec } \\
\text { ative } \\
0\end{array}$ & $\begin{array}{c}1 \mathrm{~m} \\
0\end{array}$ & onth & post & +49 & 91 & +22 & 148 & -18 & 154 & -22 & 149 \\
\hline$F \quad \frac{6525}{42}$ & +++ & + & 110 & +++ & ++ & + & ++ & 0 & 0 & 0 & 0 & 0 & 0 & -- & +60 & 134 & +11 & 212 & -7 & 272 & & \\
\hline $\begin{array}{l}\mathrm{A} 67824 \\
\mathrm{M} \quad 48\end{array}$ & + & 0 & 100 & ++ & + & + & + & 0 & 0 & 0 & 0 & 0 & 0 & $\mathbf{N}$ & +55 & 134 & +41 & 190 & +16 & 246 & & \\
\hline$\stackrel{\mathrm{A} 65385}{\mathrm{M}}$ & + & + & 85 & + & + & 0 & + & 0 & $\mathbf{T}$ & 0 & 0 & 0 & 0 & - & +51 & 130 & +20 & 146 & +3 & 157 & -13 & 154 \\
\hline $\begin{array}{l}\mathrm{A} 56133 \\
\mathrm{~F} \quad 39\end{array}$ & + & 0 & 108 & $+t$ & + & + & + & 0 & 0 & 0 & 0 & 0 & 0 & - & +59 & 151 & +21 & 170 & +7 & 277 & & \\
\hline
\end{tabular}

* Lugol's continued.

evaluated either by physical examination or $\mathbf{x}$-ray and graded + to +++ . Pulse has been recorded as the rapid rate when the patient was resting in bed soon after hospitalization. If an individual had auricular fibrillation or had been digitalized, the pulse rates have been omitted. Under tremor + indicates a perceptible fine tremor of the extended tongue or fingers of the hand, ++ an easily recognizable tremor, and +++ severe tremor obviously involving the whole body. This fine tremor of hyperthyroidism has been contrasted with the coarse Parkinson-like tremors which have been listed under brain stem disorders. Motor restlessness has been difficult to grade, but slight overactivity is described as + When activity was sufficient to make it difficult to keep a patient in bed it is graded +++ , and when the patient required a special room for management ++++ . Any perceptible exophthalmos or lid lag has been listed as + . Where all the signs of exophthalmos were present, but not marked, ++ have been used and +++ for degrees beyond this.

Under "skin" have been included flushing, sweating, and satiny texture. Different degrees of flushing and sweating have been described as + to +++ . In certain patients the flushing and the vasomotor disturbance were disproportionately great in comparison with weight loss, cardiac enlargement, thyroid involvement and height of basal metabolic rate. Such outstanding vasomotor instability has been evaluated under brain stem disorders and has been called "disproportionate vasomotor instability." Conditions which have returned or persisted 
TABLE II

Hyperthyroid patients with good recovery after thyroidectomy

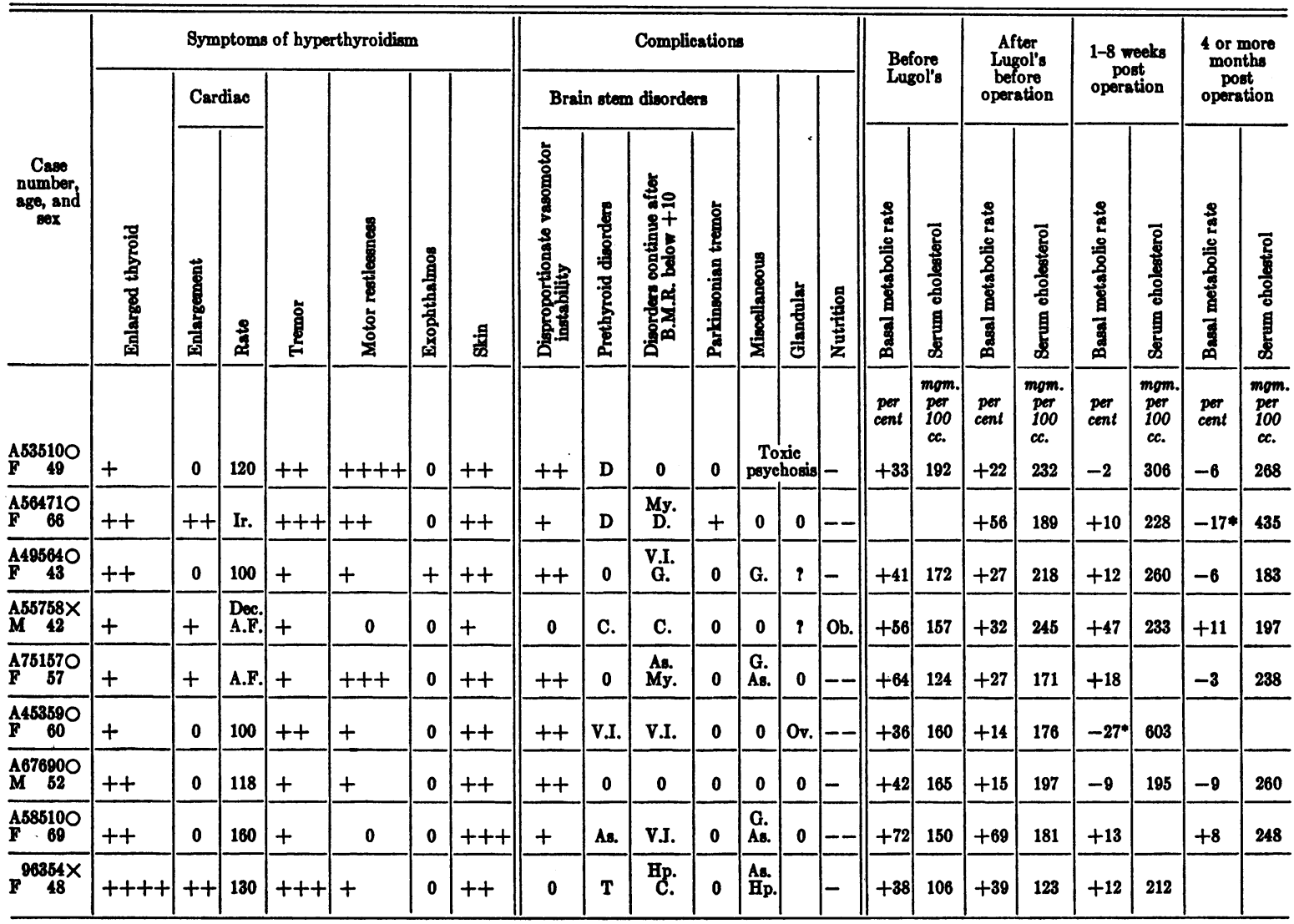

* Desiccated thyroid prescribed for thyroid deficiency symptoms.

Definition of symbols

Acr.: Acromegaly.

A.F.: Auricular fibrillation.

An.: Anemia with a red count below $3,800,000$.

As.:Arteriosclerosis as indicated by hardened or tortuous radial arteries or tortuous or nicked retinal blood vessels.

C.: Cardiac condition such as enlargement or decompensation necessitating the use of digitalis.

D.: Mental and physical depression.

Dec.: Cardiac decompensation.

E.I.: Emotional instability.

Hp.: Hypertension of $160 / 100$ or above.

G.: Severe glycosuria for which insulin was used.

Hys.: Hysterectomy.

Ir.: Irregularities in pulse other than auricular fibrillation.

M.D.: The overactivity of manic depressive psychosis.

My.: General weakness, myasthenia.

Ob.: Overweight of an extreme degree in which the distribution of fat is eccentric.

Ov.: Bilateral ovariectomy.

T.: Previous thyroidectomy or exacerbations and remissions of hyperthyroidism.

V.I.: Vasomotor instability of an extreme variety. 
TABLE III

Hyperthyroid patients with partial recovery after thyroidectomy

\begin{tabular}{|c|c|c|c|c|c|c|c|c|c|c|c|c|c|c|c|c|c|c|c|c|c|c|}
\hline & \multicolumn{7}{|c|}{ Symptoms of hyperthyroidiem } & \multicolumn{7}{|c|}{ Complications } & \multirow{2}{*}{\multicolumn{2}{|c|}{$\begin{array}{l}\text { Before } \\
\text { Lugol's }\end{array}$}} & \multirow{2}{*}{\multicolumn{2}{|c|}{$\begin{array}{c}\text { After } \\
\text { Lugol's } \\
\text { betore } \\
\text { operation }\end{array}$}} & \multirow{2}{*}{\multicolumn{2}{|c|}{$\begin{array}{c}\text { 1-8 weeks } \\
\text { post } \\
\text { operation }\end{array}$}} & \multirow{2}{*}{\multicolumn{2}{|c|}{$\begin{array}{c}4 \text { or more } \\
\text { months } \\
\text { post } \\
\text { operation }\end{array}$}} \\
\hline & & Cardi & & & & & & Brain & stem & disorder & & & & & & & & & & & & \\
\hline $\begin{array}{l}8 \\
8 \\
8 \\
8 \\
8 \\
8 \\
8 \\
8 \\
8\end{array}$ & 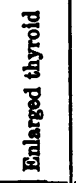 & $\begin{array}{l}\text { 若 } \\
\text { 蒠 } \\
\text { 煦 }\end{array}$ & 象 & 息 & $\begin{array}{l}8 \\
8 \\
8 \\
8 \\
8 \\
8 \\
5 \\
0 \\
0\end{array}$ & 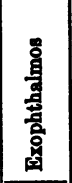 & 굥 & 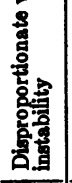 & 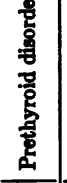 & 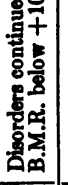 & 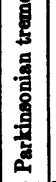 & 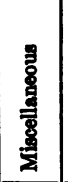 & $\frac{5}{\frac{g}{g}}$ & 总 & 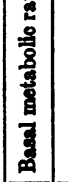 & $\begin{array}{l}\overline{8} \\
\frac{8}{8} \\
\frac{8}{8} \\
8 \\
0 \\
0 \\
8 \\
8\end{array}$ & 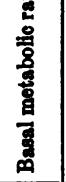 & 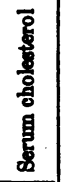 & $\begin{array}{l}\frac{8}{0} \\
\frac{0}{8} \\
\frac{8}{8} \\
\frac{8}{8} \\
\frac{7}{8} \\
\frac{8}{7}\end{array}$ & $\begin{array}{l}\overline{8} \\
8 \\
\frac{8}{8} \\
8 \\
8 \\
0 \\
8 \\
8\end{array}$ & $\begin{array}{l}\overline{6} \\
\frac{0}{8} \\
8 \\
\frac{8}{8} \\
\frac{8}{8} \\
\frac{8}{6}\end{array}$ & $\begin{array}{l}\overline{8} \\
8 \\
8 \\
\frac{8}{8} \\
8 \\
8 \\
8 \\
8\end{array}$ \\
\hline$\frac{1442430}{\mathrm{~F}} \quad 47$ & +++ & 0 & 120 & ++ & +++ & 0 & ++ & 0 & 0 & $\begin{array}{l}\text { D. } \\
\text { My. }\end{array}$ & 0 & 0 & 0 & -- & $\begin{array}{l}\text { per } \\
\text { cent } \\
+78\end{array}$ & $\begin{array}{c}\text { mom. } \\
p e r \\
100 \\
c . \\
160\end{array}$ & $\begin{array}{c}\text { per } \\
\text { cent } \\
+57\end{array}$ & $\begin{array}{c}\text { mom. } \\
\text { por } \\
100 \\
c . \\
141\end{array}$ & $\begin{array}{c}\text { per } \\
\text { cent } \\
-11\end{array}$ & $\begin{array}{c}\text { mom. } \\
\text { per } \\
100 \\
\text { ce. } \\
311\end{array}$ & $\begin{array}{c}\text { per } \\
\text { cent } \\
\\
-13\end{array}$ & $\begin{array}{c}\text { mom. } \\
\text { por } \\
100 \\
\text { cc. } \\
204\end{array}$ \\
\hline $\mathrm{A}_{54}^{452610}$ & ++ & + & 110 & ++ & +++ & ++ & ++ & 0 & M.D. & M.D. & 0 & Osteop & $\begin{array}{c}0 \\
0\end{array}$ & - & +57 & 200 & +22 & 272 & +13 & 365 & -5 & 282 \\
\hline$\frac{A 224330}{F}$ & + & 0 & 115 & + & 0 & 0 & $t$ & 0 & M.D. & $\begin{array}{l}\text { M.D. } \\
\text { My. }\end{array}$ & 0 & An. & 0 & --- & $|+57|$ & 105 & +22 & 191 & +11 & 222 & -23 & 153 \\
\hline $\begin{array}{c}A 58658 O \\
\quad 48\end{array}$ & ++ & + & 110 & ++ & ++ & 0 & ++ & $+t$ & M.D. & My. & 0 & Hp. & & -- & +47 & 146 & +10 & 196 & +5 & 243 & & 219 \\
\hline $\begin{array}{lc}\text { P } & 16920 \\
\text { P } & 60 \\
\end{array}$ & ++ & + & 95 & $+t$ & ++++ & 0 & $+t$ & + & As. & A8.D. & + & $\begin{array}{l}\text { Psych } \\
\text { with }\end{array}$ & $\begin{array}{l}\text { hosis } \\
\text { As. }\end{array}$ & --- & & & +16 & 169 & -5 & 274 & & 208 \\
\hline$F^{27339 X}$ & + & + & 90 & + & + & + & ++ & + & E.I. & E.I. & 0 & & Ob. & + & & & +15 & 124 & -4 & 246 & -2 & 202 \\
\hline $\mathrm{F}_{39}^{625} \mathrm{X}$ & ++ & \pm & 90 & ++ & ++ & 0 & + & \pm & $\begin{array}{l}\text { E.I. } \\
\text { T. }\end{array}$ & E.I. & 0 & & $?$ & + & +32 & 125 & +5 & 152 & +16 & 160 & -1 & 156 \\
\hline $\begin{array}{l}\text { A54754O } \\
\mathbf{M} 33\end{array}$ & +++ & 0 & 120 & ++ & ++ & + & $+t$ & 0 & M.D. & M.D. & 0 & 0 & 0 & - & & & +40 & 175 & & & -7 & 191 \\
\hline $\begin{array}{l}\mathrm{A} 592790 \\
\mathrm{~F} \quad 19\end{array}$ & ++ & + & 100 & ++ & + & + & ++ & ++ & E.I. & E.I. & 0 & & & -- & +34 & 154 & +18 & 186 & +4 & 262 & -11 & 261 \\
\hline $\begin{array}{|cc|}A & 92550 \\
& 61 \\
\end{array}$ & $+t$ & + & 110 & +++ & ++ & ++ & +++ & +++ & E.I. & $\begin{array}{l}\text { G.E. } \\
\text { I. }\end{array}$ & $t$ & $\mathbf{G}$ & Acr. & -- & +58 & 194 & +57 & 490 & +30 & 490 & +46 & 600 \\
\hline $\begin{array}{l}\mathrm{A} 43137 X \\
\mathrm{~F}\end{array}$ & +++ & ++ & 135 & $+t$ & $+t$ & + & ++ & 0 & T. & $\begin{array}{l}\text { My. } \\
\text { E.I. }\end{array}$ & 0 & & & -- & +45 & 173 & +21 & 195 & -16 & $395^{*}$ & & \\
\hline $\begin{array}{l}A 39091 X \\
F\end{array}$ & 0 & +++ & Dec. & + & ++ & 0 & ++ & +++ & $\begin{array}{l}\text { C.E. } \\
\text { I. }\end{array}$ & $\begin{array}{l}\text { C.E. } \\
\text { I. }\end{array}$ & 0 & $\begin{array}{l}\text { Hp. } \\
\text { A8. }\end{array}$ & & $\mathbf{N}$ & & & +39 & 208 & +4 & 354 & +2 & $380 *$ \\
\hline $\begin{array}{l}547640 \\
\mathrm{~F} \quad 35 \\
\end{array}$ & +++ & + & 130 & ++ & + & +++ & +++ & 0 & $\begin{array}{l}\text { E.I. } \\
\text { T. } \\
\end{array}$ & E.I. & $+?$ & & & -- & +73 & 135 & +28 & 177 & & & +2 & 216 \\
\hline $\begin{array}{l}\mathrm{A} 489790 \\
\mathrm{~F}\end{array}$ & $+t$ & 0 & 102 & ++ & + & + & ++ & +++ & D.I. & D.I. & 0 & & Hys. & $\mathbf{N}$ & +24 & 171 & +17 & 206 & -1 & 230 & -2 & 190 \\
\hline$F_{58}^{70165 \times}$ & + & + & 108 & ++ & + & 0 & + & 0 & $\begin{array}{l}\text { E.I. } \\
\text { T. }\end{array}$ & F.I. & 0 & & & - & +59 & 140 & +36 & 155 & $+24 t$ & 177 & & \\
\hline $\begin{array}{l}4321 \times \\
M^{58}\end{array}$ & ++ & ++ & A.F. & ++ & + & ++ & + & 0 & T. & C. & 0 & & & -- & +34 & 102 & +16 & 118 & +15 & 142 & $+3 t$ & 110 \\
\hline $\begin{array}{r}524920 \\
\quad 65 \\
\end{array}$ & ++ & + & 100 & ++ & + & 0 & ++ & 0 & E.I. & E.I. & ++ & As. & & - & +36 & 179 & +25 & 219 & -2 & 265 & & 325 \\
\hline $\begin{array}{l}A 544150 \\
F \quad 55\end{array}$ & + & ++ & 95 & + & +++ & + & ++ & ++ & $\begin{array}{l}\text { E.I. } \\
\text { G. }\end{array}$ & $\begin{array}{l}\text { E.I. } \\
\text { G. }\end{array}$ & 0 & $\begin{array}{l}\text { A8. } \\
\text { Hp. }\end{array}$ & & -- & +58 & 199 & +15 & 240 & +10 & 320 & -5 & 302 \\
\hline $\begin{array}{l}\mathrm{A} 674820 \\
\mathrm{~F} \quad 31 \\
\end{array}$ & + & 0 & 110 & + & + & ++ & +++ & ++ & M.D. & M.D. & 0 & & & -- & +32 & 141 & +20 & 136 & +2 & 212 & -10 & 202 \\
\hline $\begin{array}{l}57648 X \\
F \\
\end{array}$ & +++ & + & 100 & $+t$ & ++ & ++ & ++ & & Dy. & My. & & & Ob. & & +73 & 109 & +29 & 140 & +1 & 255 & & \\
\hline$\frac{A 619090}{F}$ & ++ & + & 120 & ++ & 0 & 0 & +++ & $+t$ & Dy. & My. & 0 & My. & & -- & +37 & 197 & +21 & 197 & -11 & 270 & & \\
\hline
\end{tabular}




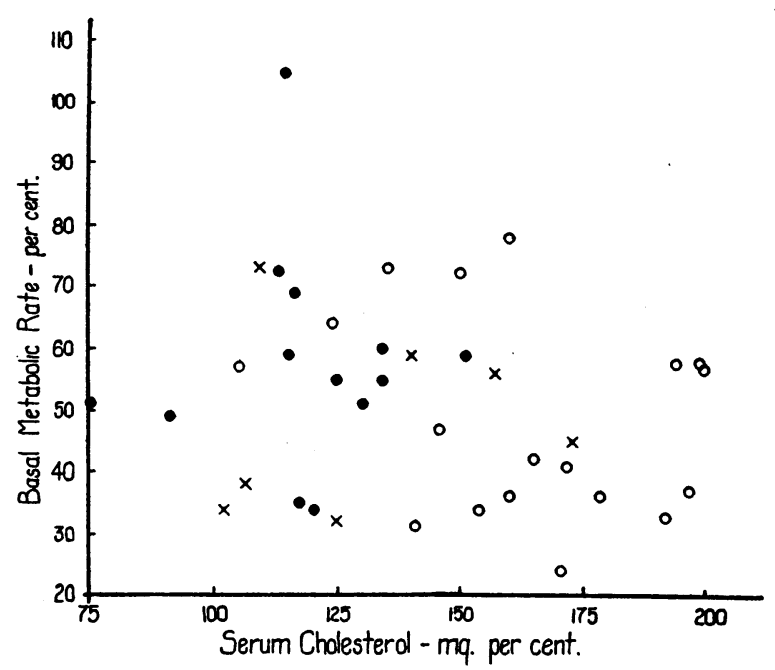

Fig. 1. Basal Metabolic Rates and Serum Cholesterols Before Treatment

Solid circles represent patients free from complicating disorders (Table I). Open circles represent patients with marked disorders of vegetative and central nervous

system. Crosses designate patients with a variety of disorders such as peculiar physical makeup or repeated exacerbations of hyperthyroidism.

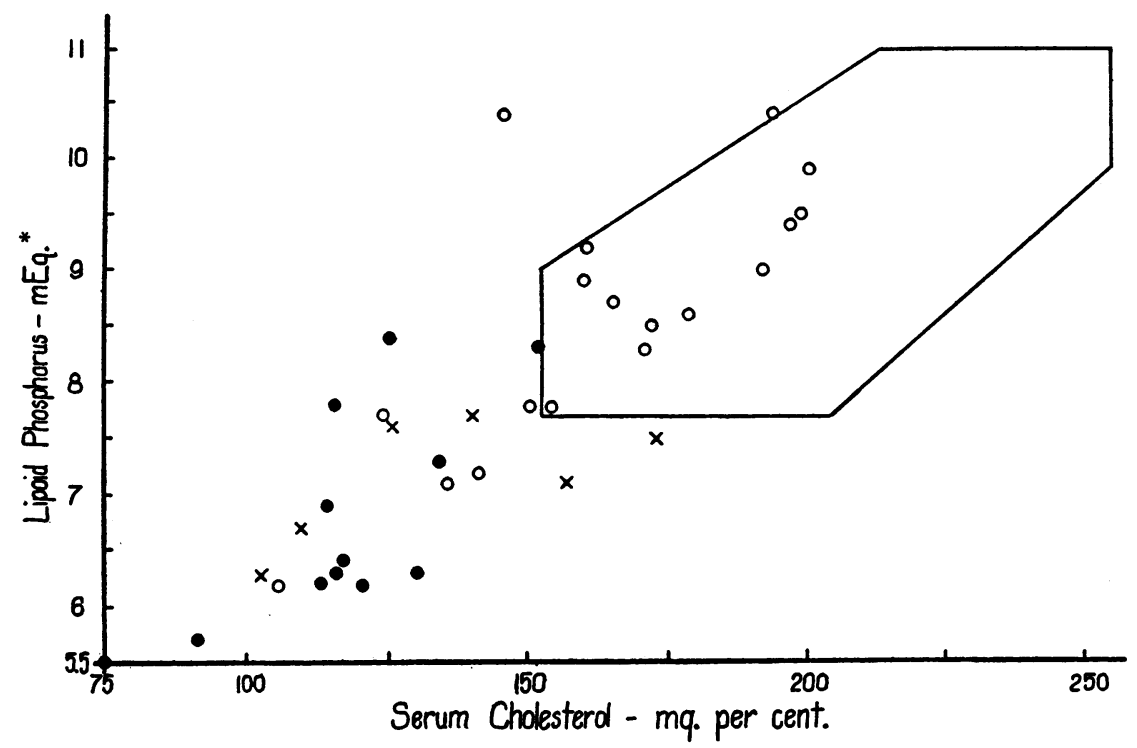

Fig. 2. Serum Cholesterol and Lipoid Phosphorus before Treatment

The same symbols have been used as in Figure 1. The hexagon indicates distribution of similar data on 95 normal men and women.

* Instead of mEq. unit should be mgm. per cent.

more than a month after thyroidectomy have been marked in the column "Disorders continue after B.M.R. below plus 10 per cent."

Nutrition has been rated as $\mathrm{N}$. when normal or average -when approximately 10 per cent of weight had been lost, and - - when emaciation was obvious, with wrinkled skin, hollow cheeks and general weakness. For people who remained distinctly well nourished, + has been used.
The serum cholesterol and basal metabolic rate are compared in Figure 1: the cholesterol and lipoid phosphorus before treatment are shown in Figure 2. Figures 3 and 5 show the changes in cholesterol and basal metabolic rate, in fatty acids and in basal metabolic rate before and after Lugol's. In Figure 4 the increases after thyroidectomy of cholesterol and lipoid phosphorus above the values before iodine therapy are illustrated.

The pathological studies of the thyroid glands of the 
patients in Tables I, II and III have been summarized in Table IV.

\section{RESULTS}

In Figure 1 it is apparent that cholesterol and basal metabolic rate were not inversely proportional. In the 13 patients with uncomplicated hyperthyroid disease represented in the chart by black circles, all cholesterols were under $151 \mathrm{mgm}$. per cent, but below this limit there is little evidence dences of extreme vasomotor instability or, in addition, disorders of the nervous system tended to have normal lipoids.

Figure 3 and the tables reveal that all but 6 of the 37 patients studied before and after Lugol's administration had decreases of 7 to 65 per cent in basal metabolic rate and increases in serum cholesterol of 10 to $100 \mathrm{mgm}$. per cent. The cholesterols of 3 (A44243, A67482, A61909) of

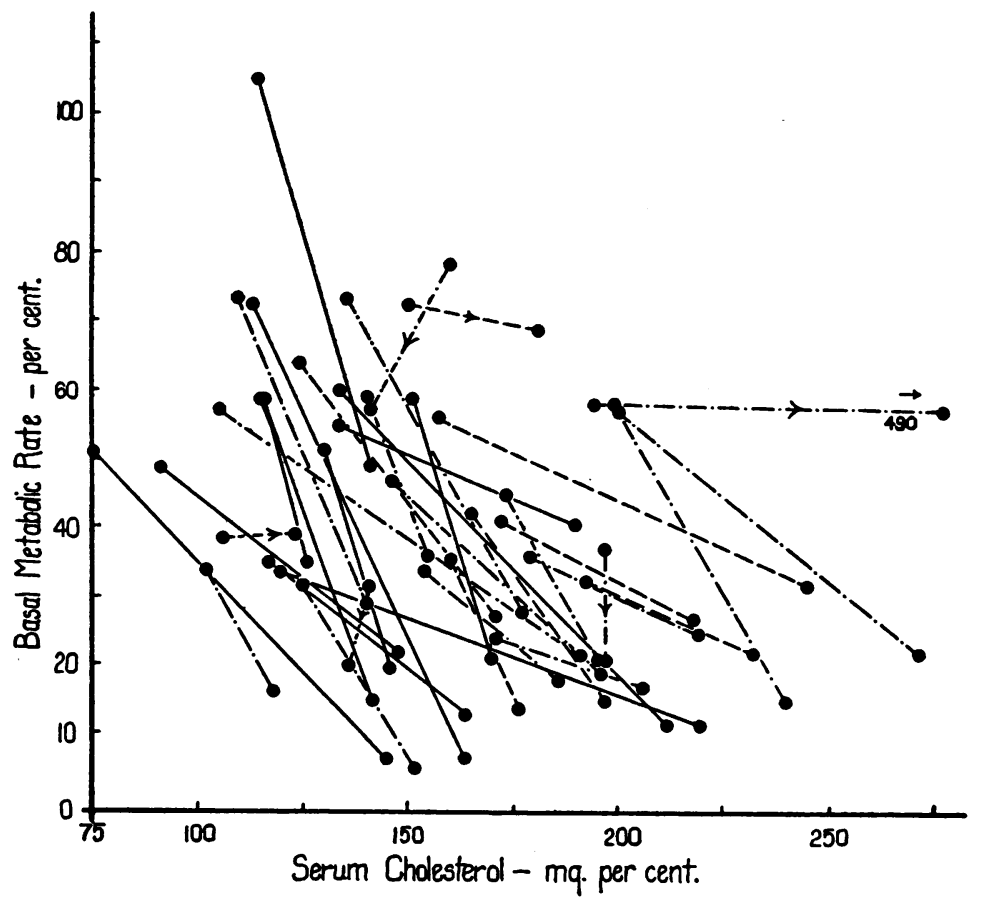

Fig. 3. Effects of Iodine Therapy on Cholesterol and Basal Metabolic Rate of 37 Patients

Lines connect the values for cholesterol and basal metabolic rate before Lugol's administration and after Lugol's administration just before operation. Solid lines for uncomplicated patients of Table I; broken lines for patients who made a good recovery after thyroidectomy (Table II); lines with a dot and a dash for patients who had a partial recovery after thyroidectomy (Table III). The 6 patients, represented by lines which do not follow the slope of the majority of the lines, have been marked by arrows and are discussed in the text.

of an inverse relationship with basal metabolic rate. This lack of relationship can be attributed somewhat to the great variability in the levels of serum cholesterol.

Inspection of Figure 2 reveals that all of the patients who were free from complications had serum cholesterol and phospholipoid values well below normal. In contrast, patients with evi- the 6 patients represented by lines, marked by arrows which do not follow the direction of the majority of the lines, did not increase; cholesterols of 3 others (A58510, 96354, A9255) increased but the basal metabolic rates did not change more than 3 per cent. The 3 patients whose cholesterols did not increase all had initial cholesterols ranging between 141 and $197 \mathrm{mgm}$. 


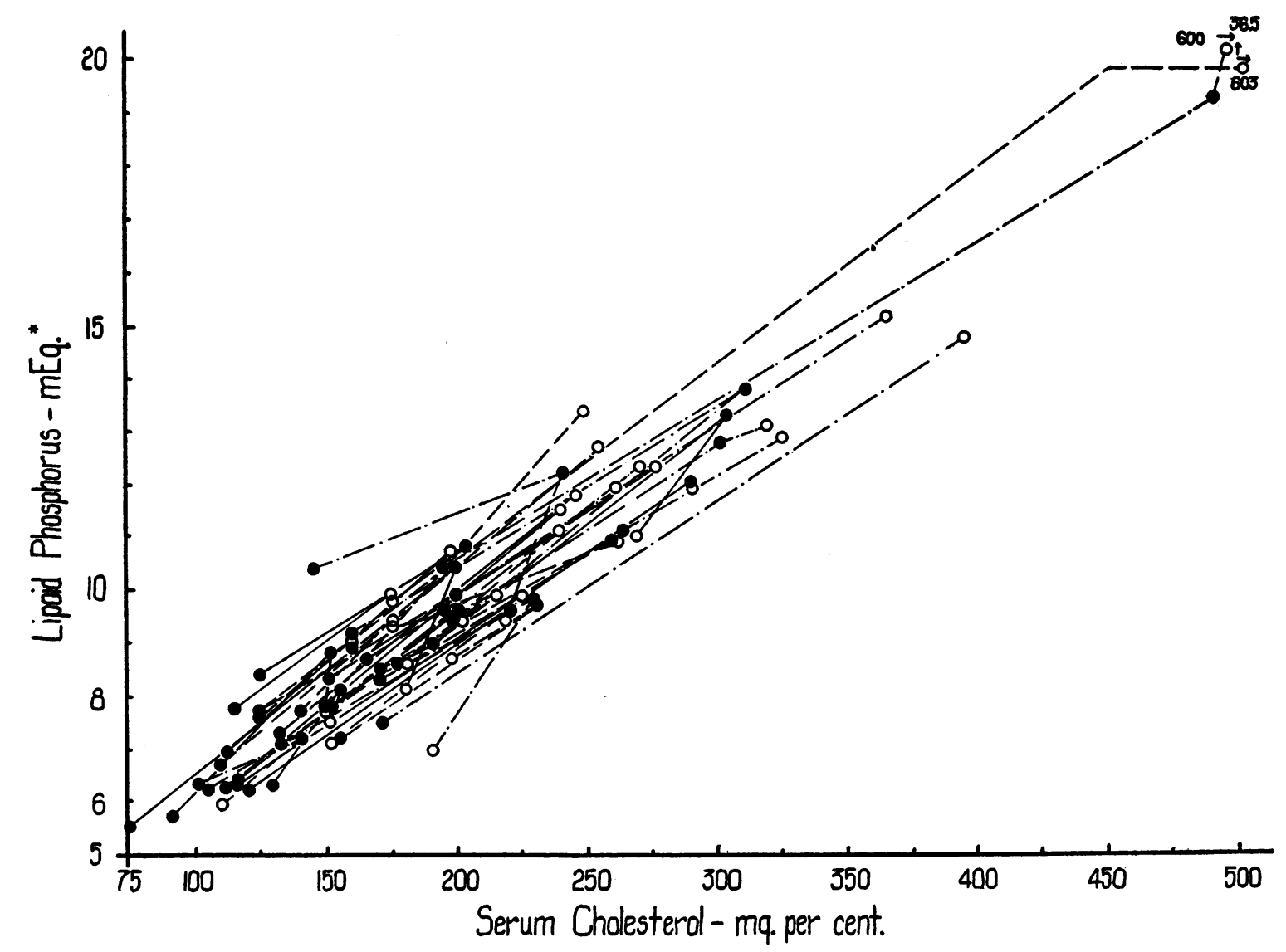

Fig. 4. Effects of Thyroidectomy on Serum Cholesterol and Lipoid Phosphorus of 32 Pattents

Lines similar to those in Figure 3 connect the values before Lugol's administration and 1 to 8 weeks after thyroidectomy, and in 18 patients 4 or more months after thyroidectomy. The final study on each patient, whether 1 to 8 weeks or 4 or more months after thyroidectomy, is represented by an open circle.

* Instead of mEq. unit should be mgm. per cent.

per cent, and exhibited symptoms of vasomotor instability, myasthenia, depression and anxiety of a marked degree. These symptoms have been shown by the authors (20) to be correlated with a lability in serum lipoids which may account for the apparent lack of response of serum cholesterol to the administration of Lugol's solution. They were also patients who were only slightly improved by thyroidectomy. Pathologically, A44243 had a colloid goiter with only a little hyperplastic tissue; A67482 also had little hyperplasia which was irregularly distributed and there were islands of epithelial metaplasia ; the gland of A61909 was indistinguishable from the glands of uncomplicated patients in Table $I$. Of the 3 patients whose basal metabolic rates were not appreciably lowered by Lugol's solution, 1 (A9255) had acromegaly. The gland of the acromegalic (A9255) had only scattered areas of hyperplastic tissue, no high columnar epithelium and, in most areas, fairly normal looking colloid. There was a considerable amount of interstitial hyaline. The second (96354) had the most grossly enlarged thyroid of all the patients in the tables and histologically the gland contained a good deal of colloid but also had local areas of hyperplastic tissue. The third (A58510), 69 years old, had arteriosclerosis, vasomotor instability, and glycosuria for which she required insulin before thyroidectomy. An adenoma was found without much evidence of hyperplastic tissue.

Subtotal thyroidectomy was followed in all patients by a rise in serum cholesterol and a fall in basal metabolic rate. The cholesterols before the administration of Lugol's and 1 to 8 weeks after operation have been considered quantitatively 
in only 30 of the 43 patients. In 4 patients (A75157, A58510, A54754, A54764) the followup study was 4 or more months after operation, and in 5 patients (A56471, P1692, 27339, A54754, A39091) there was no study before the administration of Lugol's. Eight weeks after thyroidec- dividuals. The thyroids of these 4 patients were not remarkable, with the exception of 625 whose gland contained many bizarre cells that could not be classified, and there was only a small amount of hyperplasia. Since the normal variation in cholesterol has been found to be $59 \mathrm{mgm}$. per cent

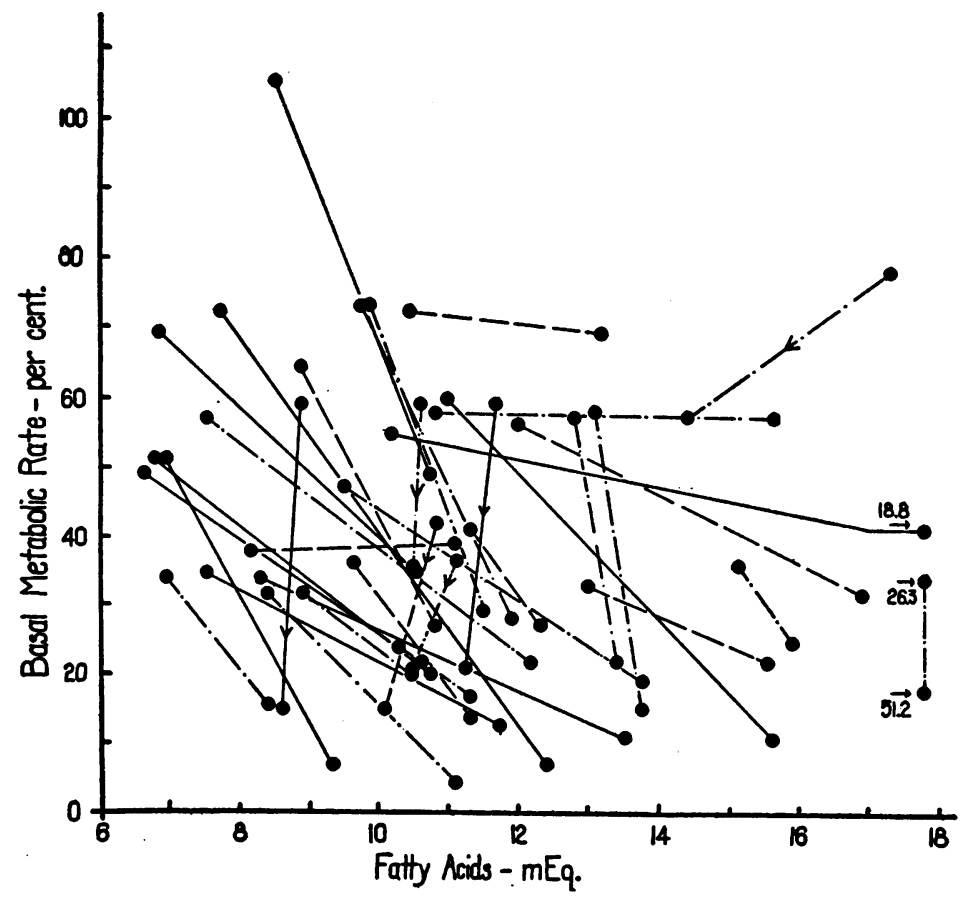

Fig. 5. Effects of Iodine Therapy on the Basal Metabolic Rate and Serum Fatty Acids of 37 Patients

The lines representing the patients in Table I, II and III are similar to those in Figure 3. The same distance represents 3 milliequivalents of fatty acids as was used for $\mathbf{5 0} \mathrm{mgm}$. per cent of cholesterol in Figure 3. These amounts are considered to be equivalent because the normal range of cholesterol varies from 150 to $250 \mathrm{mgm}$. per cent and the normal range for fatty acids from 9 to 16 milliequivalents $(19,33,34)$ and because in a normal subject cholesterol may change by as much as about $50 \mathrm{mgm}$. per cent and fatty acids by about 3 milliequivalents (35). Arrows mark the lines which do not follow the general trend and show a decrease in fatty acids rather than an increase after Lugols.

tomy, 2 patients (A45359, A43137) who showed marked symptoms of thyroid deficiency, 2 patients (A67824, 70165) who were still taking Lugol's solution, and the acromegalic patient (A9255) all showed sufficiently atypical symptoms to be excluded from the quantitative comparison of cholesterol before Lugol's and 8 weeks after operation. In the 30 typical patients serum cholesterol increased by 59 to $169 \mathrm{mgm}$. per cent in 26 subjects and increased by 27 to $40 \mathrm{mgm}$. per cent in 4 in-
(35), 26 of the 30 patients exhibited significant increases in cholesterol. The average of the 30 cholesterols before Lugol's was 139 and 1 to 8 weeks after operation $235 \mathrm{mgm}$. per cent.

This comparison of the serum cholesterols before Lugol's and 1 to 8 weeks after thyroidectomy was made at this interval because 11 of the $26 \mathrm{pa-}$ tients studied more than 4 months after thyroidectomy have shown a tendency for the cholesterol to rise abruptly soon after operation and then to 
fall and assume a level after more time elapsed. The first patient in Table $I$, the first 4 patients in Table II, and the first 6 patients in Table III exhibited this leveling off after the noticeable postoperative rise. In 1 patient the table does not give space for the blood studies continued some years which made the leveling process more obvious. A56471 (Table II), after her cholesterol had risen to $435 \mathrm{mgm}$. per cent, was given one grain of desiccated thyroid per day for about a year and a half. Thyroid was stopped completely and 8 months later the cholesterol was $237 \mathrm{mgm}$. per cent A patient (A78256) not listed in this paper had a serum cholesterol of $383 \mathrm{mgm}$. per

TABLE IV *

Comparison of histological findings in the thyroids of patients in Tables I, II and III

\begin{tabular}{|c|c|c|c|c|c|}
\hline \multirow{2}{*}{$\begin{array}{c}\text { Case } \\
\text { number }\end{array}$} & \multicolumn{2}{|c|}{$\begin{array}{l}\text { Character of } \\
\text { epithelium }\end{array}$} & \multirow{2}{*}{$\begin{array}{c}\text { Amount } \\
\text { of } \\
\text { colloid }\end{array}$} & \multirow{2}{*}{$\begin{array}{c}\text { Hyper- } \\
\text { plasia }\end{array}$} & \multirow{2}{*}{ Remarks } \\
\hline & $\underset{\text { columnar }}{\text { High }}$ & $\begin{array}{c}\text { Papillary } \\
\text { projec- } \\
\text { tions }\end{array}$ & & & \\
\hline
\end{tabular}

UNCOMPLICATED HXPERTHYROID PATIENTS, (I)

\begin{tabular}{|c|c|c|c|c|}
\hline $\begin{array}{l}28216 \\
\text { A56897 } \\
\text { A44838 } \\
\text { A65412 } \\
\text { A82427 } \\
\text { A65387 } \\
\text { A58933 } \\
8850 \\
\text { A59140 } \\
6525 \\
\text { A67824 } \\
\text { A65385 } \\
\text { A56133 }\end{array}$ & $\begin{array}{l}+++ \\
++ \\
++ \\
+++ \\
++ \\
+++ \\
+t \\
+ \\
++ \\
+++ \\
+++ \\
++t \\
++\end{array}$ & $\begin{array}{l}+++ \\
+ \\
++ \\
+++ \\
++t \\
+++ \\
++ \\
+++ \\
+++ \\
++ \\
+t \\
+t+ \\
+\end{array}$ & $\begin{array}{l}\bar{t} \\
+ \\
\bar{y} \\
\bar{t} \\
+ \\
+ \\
\bar{t} \\
\frac{1}{+}\end{array}$ & $\begin{array}{l}+++ \\
++ \\
+++ \\
+++ \\
+++ \\
+++ \\
++ \\
++ \\
++ \\
+++ \\
+++ \\
+++ \\
++\end{array}$ \\
\hline
\end{tabular}

HYPERTHYROID PATIENTS WITH COMPLICATIONS WHO MADE GOOD RECOVERY AFTER THYROIDECTOMY, (II)

\begin{tabular}{|c|c|c|c|c|c|}
\hline $\begin{array}{l}\text { A53510 } \\
\text { A56471 } \\
\text { A49564 } \\
\text { A55758 } \\
\text { A75157 } \\
\text { A45359 } \\
\text { A67690 } \\
\text { A58510 } \\
\text { 96354 }\end{array}$ & $\begin{array}{l}++ \\
++ \\
+ \\
+ \\
++ \\
++ \\
++t \\
++\end{array}$ & $\begin{array}{l}++ \\
+ \\
++ \\
++ \\
+++ \\
+\end{array}$ & $\begin{array}{l}+ \\
++ \\
++ \\
+t \\
+ \\
+ \\
++ \\
++ \\
++\end{array}$ & $\begin{array}{l}++ \\
++ \\
++ \\
+ \\
++t \\
+ \\
+ \\
++\end{array}$ & $\begin{array}{l}\text { Adenoma } \\
\text { Adenoma } \\
\text { Adenoma } \\
\text { Carcinoma } \dagger \\
\text { Adenoma }\end{array}$ \\
\hline
\end{tabular}

* Customary pathological terms have been used in describing the thyroid glands. Comparative degrees of pathological change have been graded $t$ to +++ . Dashes indicate almost entire absence of characteristic at head of column.

† Adenoma in which there was sufficient distortion of structure to suggest carcinoma.
TABLE IV-Continued

HYPERTHYROID PATIENTS WITH COMPLICATIONS WHO MADE PARTIAL RECOVERY AFTER THYROIDECTOMY, (III)

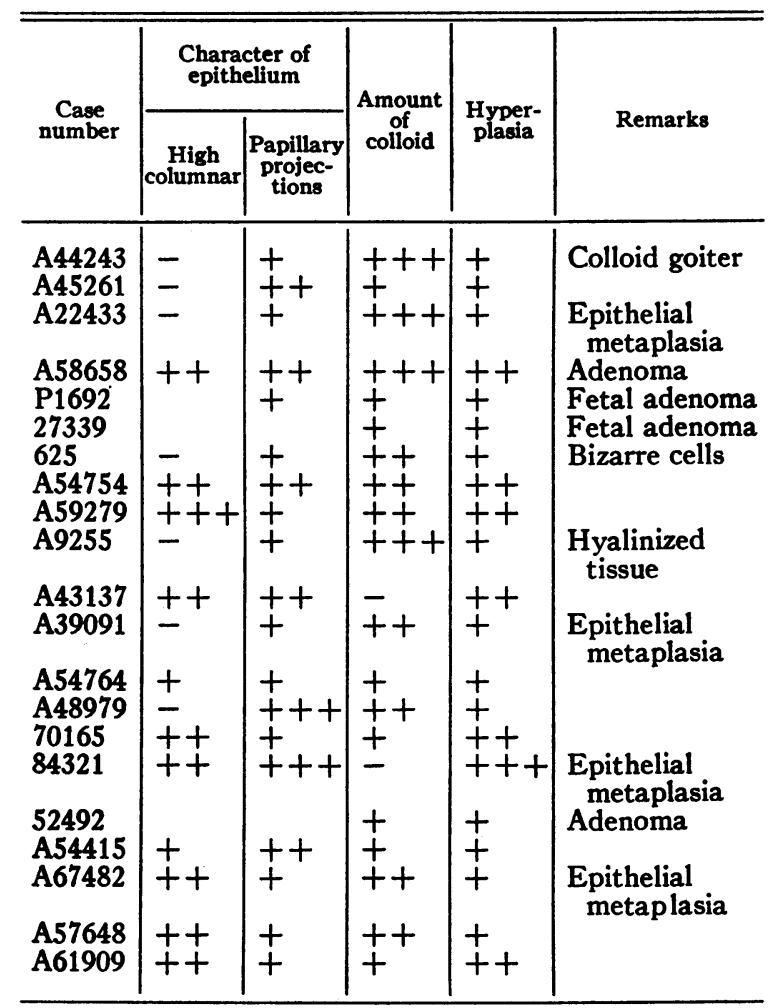

cent and symptoms of hypothyroidism soon after thyroidectomy. After a short course of desiccated thyroid, the symptoms of hypothyroidism disappeared and did not return and the serum cholesterol was maintained at about $250 \mathrm{mgm}$. per cent. The correlation between serum cholesterol and thyroid deficiency has been discussed in another paper (21). However, the evidence given in relation to the level of cholesterol before and after Lugol's solution, before and after thyroidectomy, and before and after the administration of desiccated thyroid, demonstrates a decided correlation between the level of serum cholesterol and the activity of the circulating thyroid hormone in the individual.

Serum lipoid phosphorus values were so closely related to serum cholesterol values that one may be predicted from the other. This relationship is obvious in Figure 2 in which the initial values for each component are shown. The relationship is also clear in Figure 4 in which the points representing each component in 32 individuals before 
Lugol's, 1 to 8 weeks after thyroidectomy and in 18 individuals 4 or more months after operation, have been connected by lines. All these lines have approximately the same slope. The increases in serum cholesterol during the interval of Lugol's administration and 1 to 8 weeks after operation were accompanied by proportionate increases in lipoid phosphorus. In those patients studied 4 or more months after thyroidectomy, there was equally good correlation. If the cholesterol decreased and assumed a lower level, the phosphatides behaved similarly. The same relationship existed between lipoid phosphorus and cholesterol before and after Lugol's administration. The lipoid phosphorus of 29 of the 34 patients studied at this interval increased, the phospholipoids of only 1 (A45359) diminished. In 4 individuals the changes were less than $0.3 \mathrm{mgm}$. per cent of lipoid phosphorus, or within the experimental error of the method.

Values of serum fatty acids were proportional to those of serum cholesterol, but not as precisely as were those for lipoid phosphorus. The fatty acids were studied before and after Lugol's in 37 patients and are shown graphically in Figure 5 . The fatty acids of 31 patients rose after Lugol's while, as has been shown, the cholesterol of 34 of the 37 patients rose after Lugol's. Analysis of the exact figures for fatty acids, which are not included in the tables for the sake of brevity, revealed that 11 of the 37 patients had increases exceeding 3 milliequivalents of fatty acids and 11 of the 37 had increases of cholesterol exceeding 50 mgm. per cent. This analysis and a comparison of Figures 3 and 5, in which the scale for fatty acids and cholesterol were chosen to be equivalent, show that the increases in fatty acids were of approximately the same order of magnitude as the increases in cholesterol.

The fatty acids increased after thyroidectomy in all patients except A54754. He was inadequately studied with no determination of fatty acids before Lugol's or 1 to 8 weeks after operation. All of the 30 patients whose cholesterols were compared before Lugol's administration and 1 to 8 weeks after thyroidectomy had increases in fatty acids during this interval. Twenty-three had increases in fatty acids greater than 3 milliequivalents, the variation in a normal subject (35). The greatest rise in these 30 patients was 8.7 milli- equivalents of fatty acid. Twelve of 26 patients studied 4 or more months after thyroidectomy exhibited the tendency for the fatty acids to fall and level in the same manner as cholesterol leveled.

There was no consistency in the changes of total proteins, albumin and globulin as a result of Lugol's and for this reason no data or figures are given. Of 37 determinations of total protein before and after Lugol's 4 patients had no change, 16 patients had an increase, and 17 a decrease in total proteins. Of 21 determinations of albumin, 2 patients had no change, 9 had an increase, and 10 a decrease in albumin. In the 21 examinations of globulin, there was no change in 4 , an increase in 6 , and a decrease in 11 .

The serum proteins of 28 of 32 patients whose proteins were studied before Lugol's administration and after operation increased by 0.2 to 2.2 per cent. The average for the total proteins of 32 patients before Lugol's was 6.7 and after thyroidectomy 7.3 per cent. The serum albumin of 22 of the 24 patients studied before Lugol's and after operation increased by 0.1 to 1.8 per cent and decreased in 3 patients. Of 24 comparisons of serum globulin determinations before Lugol's and after thyroidectomy, 1 patient had no change, 17 had increases of 0.1 to 0.6 per cent, and 6 had decreases in globulin. The highest serum protein, albumin or globulin after operation has been used in this comparison because no tendency for the proteins to level some time after operation was obvious. However, there were excluded from these comparişons all post-operative studies which were made when a patient had symptoms of thyroid deficiency or was being given iodine for a prolonged time. The changes in total and fraction proteins were so unimportant and insignificant that the level of serum proteins has no value in the diagnosis of hyperthyroidism.

A comparison of the histological findings in the thyroids of the patients in Tables I, II, and III has been presented in Table IV. It can be seen that the glands from patients with uncomplicated hyperthyroidism in Table I were uniformly hyperplastic, while those from patients with complications, Tables II and III, were with 4 exceptions variable in appearance. It proved relatively simple to grade the amount of hyperplasia in the first group, but proved difficult in the other 2 groups due to the variability of structure in dif- 
ferent parts of the glands. For example, from a single gland in one section marked evidences of hyperplasia were present, while in the next there was adenomatous tissue and in a third islands of epithelial metaplasia. Some of these differences have been indicated in the table under remarks.

The glands from the patients with complications who made a good recovery did not differ consistently from those who made a partial recovery. It is noteworthy, however, that 5 of 9 who made a good recovery had adenomata, while only 4 out of 21 were found in those who made a poor recovery.

Although the grading of hyperplasia proved difficult, much less was found in the latter 2 groups than in the first. In fact only 1 patient from Table II and 1 from Table III were rated +++ as against 8 out of the 13 in Table $\mathrm{I}$. Little colloid was found in the glands of patients from Table I; more was found in those from Tables II and III. Thus the pathological studies failed to support differences between the 3 groups of patients in only 4 cases, A49564, A54754, 84321, and A61909.

\section{DISCUSSION}

Examination of the three tables and of Figure 2 reveals that measurement of the initial serum lipoids was of uncertain value in determining whether or not the patients would respond well to Lugol's or thyroidectomy. In Figure 2 the cholesterol and phospholipoid figures of the uncomplicated patients were low but the mean for the whole group would obviously be close to the lower limit of normal. This wide distribution of values suggests one explanation of the discordant reports in the literature, for any studies involving less than 15 or 20 patients might well have been weighted in one direction or the other. In this study, however, the majority of patients, 30 out of 43 , presented features which previous studies in this laboratory have demonstrated to be commonly associated with high serum lipoids. $\mathrm{Pa}$ tients with extreme forms of vasomotor instability, as for example certain diabetics described by Man and Peters (37), frequently have high lipoids. Another group of patients with complex vegetative system and emotional disorders indicative of hypothalamic and basal ganglia dysfunction also tends to have high lipoids (20). A55758, an obese pyknic male, had an initial cholesterol of $157 \mathrm{mgm}$. per cent. It has been shown that the cholesterol of a pyknic male usually lies in the upper limits of the normal range, 200 to $250 \mathrm{mgm}$. per cent (19). This man may, therefore, have had a real reduction in cholesterol, although this component was not below the average normal range. All of the patients above the low limits of normal in Figure 3 belonged in one or more of these categories. When these factors are considered, it is reasonable to assume that the thyroid secretion has either reduced the lipoids from levels considerably above the normal limits or that its effects are counteracted by factors which tend to elevate the lipoids.

At present the factors which control the level of blood lipoids are not sufficiently well understood to warrant the use of lipoid values in determining the advisability of thyroidectomy. In the patients with clear-cut symptoms of hyperthyroidism and no complicating features, all of whom had low lipoids, the problems of diagnosis and prognosis were relatively simple and were not further clarified by knowledge of the level of the lipoids. On the other hand, in the complicated patients, the level of the initial cholesterol was no criterion of the patient's response to thyroidectomy. For example, A53510 who had a cholesterol of $192 \mathrm{mgm}$. per cent before iodine therapy, an atypical clinical picture, and a poor response to treatment with iodine, improved after thyroidectomy as rapidly and completely as did the patients with uncomplicated hyperthyroidism. A 44243, with a cholesterol of $160 \mathrm{mgm}$. per cent, presented a similar picture, yet after thyroidectomy experienced very slow improvement and at the end of 2 years was not well enough to work. In contrast, A22433 with atypical symptoms that made the diagnosis uncertain, had a cholesterol of 105 mgm. per cent, a high basal metabolic rate, and a good response to iodine. Yet this patient experienced only a moderate temporary relief from symptoms, with later recurrence, and after more than 2 years has shown little improvement. Her condition can scarcely be attributed to recurrence of or persistence of hyperthyroidism because her basal metabolic rate remains at about minus 23 per cent. That the initial level of serum cholesterol before Lugol's administration is of little assistance in the diagnosis of hyperthyroid- 
ism has been pointed out recently by Boyd and Connell who have studied plasma lipoids in patients with anxiety syndromes (11).

The data presented in the tables have been carefully analyzed to see whether the reaction of the individuals' serum cholesterols to Lugol's administration may be of aid in deciding whether to operate. The cholesterols of 13 of the $37 \mathrm{pa}$ tients studied before and after iodine therapy did not increase by as much as $30 \mathrm{mgm}$. per cent. Of these 13, 2 (A45359, A43137) for several years since thyroidectomy have required desiccated thyroid for the relief of myxedema. Four (A65385, 96354, 70165, 84321) had had earlier exacerbations of hyperthyroid symptoms and had been given Lugol's for a time some months or years previously. In 3 patients the basal metabolism decreased definitely after iodine although the cholesterols did not rise significantly. One (A58933) was a severely malnourished leptosomic male. His cholesterol normally was probably low (19) and the small increase after $\mathrm{Lu}$ gol's from 116 to $126 \mathrm{mgm}$. per cent may be associated with his expected low normal level. The cholesterol of 2 females (8850, A56133) who clinically exhibited adequate responses to thyroidectomy increased only from 115 to 142 and from 151 to $170 \mathrm{mgm}$. per cent; but the cholesterolemia after Lugol's may have been close to the normal for them. Four (A44243, 625, A67482, A61909), of whom all but 625 did not have a satisfactory response in basal metabolic rate to iodine therapy, had very little improvement after thyroidectomy and for 6 months and longer remained fatigued and nervous although the pronounced exophthalmos of the right eye of A67482 improved decidedly.

Just as the basal metabolic rate does not always fall when Lugol's is given, the cholesterol may not always rise because the hyperthyroid condition may be progressing to such an extent that iodine is unable to do more than neutralize the effect of the increasing hyperthyroidism. A patient, A82380, not in this series, gives an example of a fall in serum cholesterol parallel with a progression of hyperthyroid symptoms when she was not taking iodine. She had a basal metabolic rate of plus 1 and a cholesterol of $148 \mathrm{mgm}$. per cent, but disproportionate hyperthyroid symptoms. When given Lugol's for 2 months, she had little symptomatic relief and the basal rose to plus 10 per cent. No lipoids were determined at this date. Five weeks after Lugol's was stopped her basal was plus 25 per cent and the cholesterol had fallen to $129 \mathrm{mgm}$. per cent. She was given Lugol's and the basal fell to plus 8 per cent, while the cholesterol rose to $175 \mathrm{mgm}$. per cent. In the intermediate period without iodine therapy and with progression of hyperthyroid symptoms, the cholesterol fell from 148 to $129 \mathrm{mgm}$. per cent. In comparing cholesterols before and after Lugol's, one may well take into account an aggravation in the hyperthyroid condition which would tend to lower the serum cholesterol and thus cancel any effect of iodine therapy on the level of serum lipoids.

The diagnostic value of serum cholesterol determination is slight, but it does supply corroborative evidence of the more important clinical observations and behavior of the basal metabolic rate. It may be of use when accurate basal determinations cannot be obtained. If the patient does not improve clinically, if the basal does not fall, and if the cholesterol fails to rise after Lugol's, thyroidectomy probably will not be effective. Whether the reverse can be stated with equal assurance is still uncertain. Three patients (A2875, P1237, P1529), not in this series, with slightly increased basals who did not conform to the hyperthyroid picture, were all given Lugol's. Their cholesterols increased from 139 to 200, from 194 to 266 , and from 185 to $269 \mathrm{mgm}$. per cent. For clinical reasons they did not have thyroidectomies and therefore as test cases they were quite unsatisfactory. Two patients (A53920, A61169), not included in this series, with extreme vasomotor instability, diabetes requiring insulin, tachycardia, arteriosclerosis, and who lacked the typical symptoms and signs of hyperthyroidism, had basal metabolic rates of plus 29 and plus 24 per cent. The cholesterols of both fell equivocally after Lugol's from 312 to 279 and from 270 to 265 mgm. per cent respectively. The basal responses were quite as uncertain. Again operation seemed unjustifiable and therefore the significance of the relation between atypical lipoid response to iodine and atypical symptoms must remain a subject for speculation. That increases in serum cholesterol are the usual responses of hyperthyroid patients to iodine therapy has been pointed out by Hurx- 
thal (24), Bartels $(1,3)$, and by Nicholls and Perlzweig (41) who also found increases in fatty acids. What the behavior of the serum cholesterol of a non-hyperthyroid patient is after iodine administration does not seem to have been completely investigated. Turner (50) found no significant change in the serum cholesterol of 9 out of 10 non-hyperthyroid patients given 2 grams of potassium iodide daily for 4 to 6 weeks. The cholesterol of the exceptional patient, a female diabetic, rose from the abnormally high average of $384 \mathrm{mgm}$. per cent before potassium iodide to an average of $434 \mathrm{mgm}$. per cent during the iodide administration.

No correlation was found between the height to which the lipoids rose after thyroidectomy and the degree of recovery. Two of the patients whose initial lipoids were low showed after thyroidectomy little rise in serum cholesterol and other lipoids, although the basal metabolic rates fell below zero, and they experienced marked clinical improvement. One of these patients (A59140) is also remarkable because of the development of a unilateral exophthalmos in the course of convalescence. The other patient (A65385) illustrates how slight the rise in cholesterol may be even when the basal metabolic rate falls to minus 13 and there is definite clinical improvement. The lipoids of 11 of 26 patients studied more than 6 months tended to level off after the usual postoperative rise. This fall in lipoids occurred in the absence of a concomitant rise in basal metabolic rate. The first patient in Table I, the first 4 in Table II, and the first 6 in Table III belong in this group. This fall in cholesterol several months after thyroidectomy has been previously reported by Hurxthal $(24,25)$.

The 21 patients who presented symptoms of nervous system disorder as well as hyperthyroidism were partly relieved of symptoms by thyroidectomy but their subsequent courses progressed or failed to progress independently of the level of basal metabolic rate or serum lipoids. Patients A44243, A45261, A22433, and A54754 illustrate various responses of this type.

The 5 patients with sufficiently severe diabetes to require insulin for control before thyroidectomy varied considerably after operation. A75157 and A58510, who did well after thyroidectomy, no longer required insulin; A49564 and A54415 were improved but continued to require insulin. These patients presented a complex variety of symptoms but they all had in common vasomotor instability and other nervous system disorders which were possibly due to a primary disorder of the vegetative centers in the brain stem. Patient A9255 represents an extreme form of the breakdown of these regulative mechanisms. The pituitary gland may have played a rôle but the persistent and gross tremor and extreme vasomotor instability indicate the presence of a disorder in the brain stem.

It is noteworthy that the subsequent comparative investigation of the pathology of the thyroid glands of these patients lends support to their classification into at least 2 groups. The glands from the clinically uncomplicated patients, Table I, proved to be uniformly and moderately ++ to severely +++ hyperplastic, while those from patients with complications presented numerous variations in structure and usually less clear-cut evidences of hyperplasia (Table IV).

Difficulties were encountered in evaluating the degree of malnutrition from the history and the general appearance of the patient. The nutritional condition of the patients in the present study is of interest because there is considerable evidence that malnutrition induced by a variety of conditions may lower the serum lipoids (33). On the basis of the story of weight loss and clinical appearance, all but 9 of the 43 patients had lost weight markedly. When the per cent of weight loss was plotted against cholesterol in mgm. per cent, no relation between these two values could be discovered. On the other hand, the evidence derived from the protein and albumin studies indicates that in some patients these substances suffered a depletion similar, if less severe in degree, to that found in malnourished patients. Bartels $(2,3)$ has reported a depletion below normal levels in total proteins, and in some hyperthyroid patients, in albumin before treatment. In his 59 cases 3 months after thyroidectomy the total proteins and albumin were normal. $\mathrm{He}$ attributes these findings to the state of the liver rather than to the nutritional status or to changes in hemoconcentration. Brown and Mecray (12) have also reported a rise in proteins after thyroidectomy. In 32 of the patients in Tables I, II, and III, the mean value for the total proteins 
before operation was 6.7 per cent and after convalescence rose to 7.3 per cent. Patients who required desiccated thyroid or prolonged iodine therapy during convalescence were excluded from this comparison. The latter figure approximates that found in well nourished people by Bruckman, D'Esopo and Peters $(14,46)$. This rise in proteins may have been due to the simultaneous improvement in nutrition, but it may also be affected in part by hemoconcentration. The results of the measurements of the albumin and globulin fractions are not sufficiently clear-cut to differentiate between these two possibilities. Gibson has reported that " in 25 cases of hyperthyroidism the blood volume was increased above normal on an average of 5.45 per cent" (18). In 14 subjects the increase occurred in both protein fractions and consequently it is possible that hemoconcentration may have been responsible for the change. The fact that the albumin increased more markedly than the globulin indicates that hemoconcentration may not have been important and that the small rise was probably due to improvement in nutrition.

A correlation between the 3 lipoid fractions, total fatty acids, phosphatides and cholesterol with thyroid activity in a single individual is apparent from the analysis of the results. Changes in cholesterol were accompanied by proportionate alterations in phospholipoids and by slightly more variable changes in total fatty acids. If the proteins are used as a criterion of blood volume, the increases in lipoids greatly exceed any diminution in blood volume. The post thyroidectomy protein was 109 per cent of the initial protein value while the post thyroidectomy cholesterol was 169 per cent of the initial value. It must be stressed that from one patient to another the height of the basal metabolic rate was not proportional to the level of serum lipoids, but the close correlation between the different lipoids was obvious in each subject as an individual. Nicholls and Perlzweig (41) found similar changes in cholesterol and fatty acids of hyperthyroid patients. Boyd and Connell $(8,9)$ have pointed out that the neutral fat was diminished less than the total lipoid, total cholesterol, free cholesterol or phospholipoids. However, Boyd in an earlier article (6) in which he described his lipoid techniques, stated that " of all the lipids, neutral fat and cholesterol ester were found to be the most variable." That neutral fat might vary greatly can be understood readily because in his method total fatty acids and total cholesterol are determined together. From this value must be subtracted the determined total cholesterol, the computed cholesterol ester fatty acids, the phospholipoid fatty acids computed as two-thirds of the phospholipoid, in order to obtain the figure for neutral fat. This fraction is therefore subject to the summation of errors. The observations of Soskin and Mirsky (49) that in a patient who refused thyroidectomy the daily feeding of 230 grams of fat supplemented by 3 grams of cholesterol for 23 days resulted in remission of hyperthyroid symptoms, are of interest in relation to the problem of lipemia in hyperthyroidism. The results of earlier workers, the data given previously, and the observations in a companion article (21) on hypothyroidism show that the level of serum lipoids is closely related to overactivity and underactivity of the thyroid gland.

\section{CONCLUSIONS}

The basal metabolic rate, serum cholesterol, lipoid phosphorus, titrated fatty acids, total proteins, albumin, globulin and pathology of thyroid glands of 43 patients with symptoms of hyperthyroidism have been studied. Blood studies were made at frequent intervals which, as often as possible, were before Lugol's administration, after iodine but before thyroidectomy, 1 to 8 weeks and 4 or more months after operation.

The level of serum lipoids before iodine therapy was not related to the height of the basal metabolism and was of little value in predicting the degree of improvement after thyroidectomy. In 13 uncomplicated patients the cholesterol before Lugol's was below $151 \mathrm{mgm}$. per cent, the lower limit of the normal range. Complex factors other than the thyroid, such as extreme vasomotor instability and vegetative nervous system disorders, have been considered in relation to the initial level of the cholesterol.

After Lugol's administration the cholesterols in 34 of 37 patients increased 10 to $100 \mathrm{mgm}$. per cent, and the basal metabolic rate of 34 of these 37 patients fell 7 to 65 per cent. This rise in cholesterol has been evaluated as a criterion to be used in considering the advisability of thyroidectomy. 
After thyroidectomy the cholesterols of all the 43 patients increased. In 26 of 30 patients studied before Lugol's and 1 to 8 weeks after operation, the increases were more than $59 \mathrm{mgm}$. per cent, and therefore more than the limits of variation in a normal individual. The cholesterol of 11 patients rose sharply soon after thyroidectomy and then fell to a constant level 4 or more months after operation. The height of the rise was not related to the degree of improvement and recovery.

Changes in cholesterol were accompanied by proportionate alterations in phosphatides and by somewhat less precise changes in fatty acids.

No consistent changes in total proteins, albumin or globulin occurred during the administration of iodine. In 28 of 32 patients the serum proteins after thyroidectomy were higher than before Lugol's by 0.2 to 2.2 per cent. The serum albumin exhibited a greater tendency to increase than serum globulin. The relation of these increases to the state of nutrition of the patients has been discussed.

The patients whose hyperthyroidism was clinically uncomplicated had glands that were uniformly hyperplastic and contained relatively small amounts of colloid. The patients whose clinical conditions were complicated had thyroids with variable histopathological pictures. There was in general less hyperplastic tissue. Many glands had adenomata, while others contained islands of epithelial metaplasia, bizarre cells, and relatively large amounts of colloid.

It would have been impossible to collect this material if it had not been for the clinical services of Dr. Paul Lavietes, Dr. C. L. Robbins, Dr. Alexander Winkler, and Dr. Kalmen A. Klinghoffer under whose care were many of the patients.

\section{BIBLIOGRAPHY}

1. Bartels, E. C., Liver function in hyperthyroidism as determined by the hippuric acid test. New England J. Med., 1937, 216, 1051.

2. Bartels, E. C., Serum-protein studies in hyperthyroidism. New England J. Med., 1938, 218, 289.

3. Bartels, E. C., Liver function in hyperthyroidism as determined by the hippuric acid test. Ann. Int. Med., 1938, 12, 652.

4. Bing, H. J., and Heckscher, H., Der Fett-Cholesteringehalt des Blutes bei Patienten mit morbus Basedowii. Biochem. Ztschr., 1925, 158, 403.
5. Bogdanovitch, S. B., and Man, E. B., The effects of castration, theelin, testosterone and antuitrin-S on the lipoids of blood, liver and muscle of guinea pigs. Am. J. Physiol., 1938, 122, 73.

6. Boyd, E. M., A differential lipid analysis of blood plasma in normal young women by microoxidative methods. J. Biol. Chem., 1933, 101, 323.

7. Boyd, E. M., The effect of thyroidectomy on blood lipids. Trans. Roy. Soc., Canad., 1936, Sect. V, 3rd Ser., 30, 11.

8. Boyd, E. M., and Connell, W. F., Thyroid disease and blood lipids. Quart. J. Med., 1936, 5, 455.

9. Boyd, E. M., and Connell, W. F., Lipopenia of hyperthyroidism. Quart. J. Med., 1937, 6, 231.

10. Boyd, E. M., and Connell, W. F., Further studies of plasma lipids in toxic goitre: Evidence suggesting a bimodal distribution. Quart. J. Med., 1939, N. S. 8, 41.

11. Boyd, E. M., Connell, W. F., and Doyle, A. M., Plasma lipids in anxiety states and their comparison with the lipopenia of hyperthyroidism. Quart. J. Med., 1939, N. S. 8, 47.

12. Brown, R. B., and Mecray, P. M., Serum proteins before and after operations for hyperthyroidism. Endocrinology, 1938, 22, 302.

13. Brown, W. T., and Gildea, E. F., Hyperthyroidism and personality. Am. J. Psychiat., 1937, 94, 59.

14. Bruckman, F. S., D'Esopo, L. M., and Peters, J. P., Plasma proteins in relation to blood hydration. IV. Malnutrition and the serum proteins. J. Clin. Invest., 1930, 8, 577.

15. Denis, W., Cholesterol in human blood under pathological conditions. J. Biol. Chem., 1917, 29, 93.

16. Epstein, A. A., and Lande, H., Studies on blood lipoids. 1. The relation of cholesterol and protein deficiency to basal metabolism. Arch. Int. Med., 1922, 30, 563.

17. Gardner, J. A., and Gainsborough, H., The relationship of plasma cholesterol and basal metabolism. Brit. Med. J., 1928, 2, 935.

18. Gibson, J. G., 2d, and Harris, A. W., Clinical studies of the blood volume. V. Hyperthyroidism and myxedema. J. Clin. Invest., 1939, 18, 59.

19. Gildea, E. F., Kahn, E., and Man, E. B., The relationship between body build and serum lipoids and a discussion of these qualities as pyknophilic and leptophilic factors in the structure of the personality. Am. J. Psychiat., 1936, 92, 1247.

20. Gildea, E. F., Man, E. B., and Biach, R. W., Long term studies of the variations in serum proteins, non-protein nitrogen and lipoids in patients with schizophrenia and manic depressive psychoses and in normal people (In press Arch. Neurol. Psychiat.)

21. Gildea, E. F., Man, E. B., and Peters, J. P., Serum lipoids and proteins in hypothyroidism. J. Clin. Invest., 1939, 18, 739.

22. Grabfield, G. P., and Campbell, A. G., A note on the relation between blood cholesterol and basal metabolic rate. New England J. Med., 1931, 205, 1148. 
23. Hurxthal, L. M., Blood cholesterol in thyroid disease. I. Analysis of findings in toxic and in nontoxic goitre before treatment. Arch. Int. Med., 1933, $51,22$.

24. Hurxthal, L. M., Blood cholesterol in thyroid disease. II. Effect of treatment. Arch. Int. Med., 1933, 52, 86.

25. Hurxthal, L. M., Blood cholesterol and thyroid disease. III. Myxedema and hypercholesteremia. Arch. Int. Med., 1934, 53, 762.

26. Hurxthal, L. M., and Hunt, H. M., Clinical relationships of blood cholesterol with a summary of our present knowledge of cholesterol metabolism. Ann. Int. Med., 1935, 9, 717.

27. Kirk, E., Page, I. H., and Van Slyke, D. D., Gasometric microdetermination of lipids in plasma, blood cells and tissues. J. Biol. Chem., 1934, 106, 203.

28. Laroche, G., Les variations de la cholestérinémie chez les thyroidiens. Presse Med., 1929, 1, 268.

29. Levy, M., Les variations du cholésterol chez les basedowiens traités par la radiothérapie. Bull. et. mém. Soc. méd. d.'hôp de Paris, 1931, 55, 1844.

30. Luden, G., Studies on cholesterol. V. The blood cholesterol in malignant disease and the effect of radium on the blood cholesterol. J. Lab. and Clin. Med., 1918, 4, 849.

31. Man, E. B., A note on the stability and quantitative determination of phosphatides. J. Biol. Chem., 1937, 117, 183.

32. Man, E. B., and Gildea, E. F., A modification of the Stoddard and Drury titrimetric method for the determination of the fatty acids in blood serum. J. Biol. Chem., 1932, 99, 43.

33. Man, E. B., and Gildea, E. F., Serum lipoids in malnutrition. J. Clin. Invest., 1936, 15, 203.

34. Man, E. B., and Gildea, E. F., Notes on the extraction and saponification of lipids from blood and blood serum. J. Biol. Chem., 1937, 122, 77.

35. Man, E. B., and Gildea, E. F., Variations in lipemia of normal subjects. J. Biol. Chem., 1937, 119, 769.

36. Man, E. B., and Peters, J. P., Gravimetric determination of serum cholesterol adapted to the Man and Gildea fatty acid method with a note on the estimation of lipoid phosphorus. J. Biol. Chem., 1933, $101,685$.

37. Man, E. B., and Peters, J. P., Serum lipoids in diabetes. J. Clin. Invest., 1935, 14, 579.

38. Mason, R. L., Hunt, H. M., and Hurxthal, L. M., Blood cholesterol values in hyperthyroidism and hypothyroidism-their significance. New England J. Med., 1930, 203, 1273.
39. McElroy, J. S., Schuman, E. B., and Ritchey, J. O., A study of the changes in serum cholesterol, gastric secretion and carbohydrate metabolism in patients with toxic goiter. Ann. Int. Med., 1938, 12, 106.

40. McGee, L. C., Blood cholesterol in disturbances of the basal metabolic rate. Ann. Int. Med., 1935, 9, 728.

41. Nicholls E. G., and Perlzweig, W. A., The plasma fats and the iodine absorption capacity of the fatty acids in hyperthyroidism. J. Clin. Invest. 1928, 5, 195.

42. Okey, R., A micro method for the estimation of cholesterol by oxidation of the digitonide. J. Biol. Chem., 1930, 88, 367.

43. Page, I. H., Kirk, E., Lewis, W. H., Jr., Thompson, W. R., and Van Slyke, D. D., Plasma lipids of normal men at different ages. J. Biol. Chem., 1935, 111, 613.

44. Parhon, C. I., and Derevici, H., Modifications de la constitution chimique du sang dans le syndrome hyperthyroparathyroidien expérimental et chez les animaux simplement soumis au traitement thyroidien. Compt. rend. Soc. de biol., 1928, 99, 246.

45. Parhon, C. I., and Ornstein, I., Influence de la thyroxine sur la cholestérolémie et la lipémie. Compt. rend. Soc. de biol., 1931, 108, 303.

46. Peters, J. P., and Eisenman, A. J., The serum proteins in diseases not primarily affecting the cardiovascular system or kidneys. Am. J. Med. Sc., 1933, 186, 808.

47. Schally, A. O., Störung und Regulation des Cholesterinstoff wechsels. II. Schilddruse und Cholesterinstoff wechsel. Ztschr. f. klin. Med., 1935, 128, 376.

48. Schoenheimer, R., and Sperry, W. M., A micromethod for the determination of free and combined cholesterol. J. Biol. Chem., 1934, 106, 745.

49. Soskin, S., and Mirsky, I. A., Medical treatment of hyperthyroidism with a high fat diet. J. A. M. A., 1938, 110, 1337.

50. Turner, K. B., and Steiner, A., A long term study of the variation of serum cholesterol in man. J. Clin. Invest., 1939, 18, 45.

51. Wade, P. A., Clinical and experimental studies on calcium and cholesterol in relation to the thyroid parathyroid apparatus. Am. J. Med. Sc., 1929, 177, 790.

52. Weber, M. R., Das Verhalten einiger biochemischer Blutkomponenten bei operativer Behandlung der Basedowschen Krankheit. Ztschr. f. klin. Med., 1931, 118, 464.

53. Yasuda, $M$., Contributions to the micro determination of cholesterol. J. Biol. Chem., 1931, 92, 303. 